\title{
NILAI CERNA PROTEIN IN-VITRO BISKUIT DENGAN SUBSTITUSI KECAMBAH KEDELAI (Glycine max (L.) MERRIL) DAN PISANG (Musa paradisiaca Sp.) SEBAGAI MAKANAN SEHAT UNTUK ANAK SEKOLAH DASAR
}

\author{
Dayita Asri Kanaka, Fitriyono Ayustaningwarno*) \\ Program Studi Ilmu Gizi Fakultas Kedokteran Universitas Diponegoro \\ Jl.Dr.Sutomo No.18, Semarang, Telp (024) 8453708, Email : gizifk@ undip.ac.id
}

\begin{abstract}
Background : Protein quality of foods not only depends on protein content and amino acid composition, but also their digestibilities. Soybean is one of plant protein sources which contains antinutrition compounds that can inhibit mechanism of digestive enzyme. Method to decrease the antinutrition compounds is by germination. Sprouted-soybean flour is less accepted because of the off-flavour. Banana flour has good flavour and also rich of vitamin, mineral, and dietary fiber. The making of biscuits with sprouted-soybean and banana substitution can be a healthy food for schoolchildren in nutritional value, protein digestibility and sensory aspects.

Objective : To analyze the in-vitro protein digestibility of biscuits with sprouted-soybean and banana substitution.

Methods : This is a complete randomized single factor design study. Substitution of sprouted-soybean flour and banana flour $(0 \%, 12,5 \%, 25 \%, 37,5 \%$ and 50\%) were added to biscuits to analyze its effect on in-vitro protein digestibility. Collected data were analyzed by Kruskal-Wallis test continued by Mann-Whitney test.

Result : Protein digestibilities of each sprouted-soybean flour and banana flour substitution percentage $10 \%, 12,5 \%$, $25 \%, 37,5 \%$ and $50 \%$ ) were $96.5 \%, 93.1 \%, 90.4 \%, 91.3 \%$ and $88.9 \%$, respectively. There was a significant difference of in-vitro protein digestibility between control group and biscuits with sprouted-soybean flour and banana flour substitution group.

Conclusion : All group of biscuits has high protein digestibility (88.9-96.5\%). There was a decline of protein digestibility following the addition of sprouted-soybean flour and banana flour.
\end{abstract}

Keywords : biscuits, sprouted-soybean, banana, protein digestibility

\begin{abstract}
ABSTRAK
Latar Belakang : Mutu protein bahan pangan tidak hanya ditentukan berdasarkan kandungan protein dan komposisi asam aminonya saja, tetapi juga nilai cernanya. Kedelai merupakan sumber protein nabati yang mengandung senyawa antinutrisi sehingga dapat menghambat kerja enzim pencernaan. Metode untuk mengurangi senyawa antinutrisi tersebut yaitu dengan perkecambahan. Kecambah kedelai yang ditepungkan masih kurang dapat diterima karena masih tersisanya aroma langu. Pisang dapat sebagai pemberi aroma dan juga kaya akan vitamin, mineral dan serat pangan. Pembuatan biskuit dengan substitusi kecambah kedelai dan pisang dapat menjadi makanan sehat untuk anak sekolah dasar, baik dari segi kandungan gizi, nilai cerna protein maupun nilai sensorisnya.

Tujuan : Menganalisis nilai cerna protein in-vitro biskuit yang disubstitusi dengan kecambah kedelai dan pisang.

Metode : Merupakan penelitian dengan rancangan acak lengkap satu faktor, yaitu persentase substitusi tepung kecambah kedelai dan tepung pisang (0\%, 12,5\%, 25\%, 37,5\% dan 50\%) pada biskuit untuk mengetahui pengaruhnya terhadap nilai cerna protein in-vitro pada biskuit. Data yang terkumpul dianalisis menggunakan uji Kruskal-Wallis dengan uji lanjut Mann-Whitney.

Hasil : Nilai cerna protein in-vitro dari setiap persentase substitusi tepung kecambah dan tepung pisang $10 \%, 12,5 \%$ 25\%, 37,5\% dan 50\%) adalah 96.5\%, 93.1\%, 90.4\%, 91.3\% dan 88.9\%. Terdapat perbedaan nilai cerna protein yang bermakna antara kelompok biskuit kontrol dengan kelompok biskuit substitusi kecambah kedelai dan pisang.

Simpulan : Semua kelompok biskuit memiliki nilai cerna protein yang tinggi (88.9-96.5\%). Terjadi penurunan nilai cerna protein biskuit seiring dengan penambahan substitusi tepung kecambah kedelai dan pisang.

Kata kunci : biskuit, kecambah kedelai, pisang, nilai cerna protein
\end{abstract}

\section{PENDAHULUAN}

Makanan jajanan menjadi bagian yang tidak terpisahkan dari kehidupan anak sekolah dasar. Dewasa ini banyak makanan jajanan yang hanya mengandung tinggi kalori, tinggi lemak dan tinggi gula tanpa memperhatikan kebutuhan zat gizi lainnya seperti protein, mikronutrien dan serat. Sebanyak 90,65\% anak sekolah dasar memiliki frekuensi jajan sering yaitu $\geq 5$ kali per minggu dengan total energi konsumsi makanan jajanan adalah $326 \mathrm{kkal}$ atau lebih tinggi dari kebutuhan yaitu 180 kkal untuk anak usia 7-9 tahun dan 205 kkal untuk usia 10-12 tahun. ${ }^{1}$ Frekuensi konsumsi makanan jajanan yang berlebihan berhubungan positif dengan kegemukan dan obesitas. ${ }^{2}$ Obesitas dapat menjadi faktor risiko dari berbagai macam penyakit degeneratif. Untuk itu dibutuhkan 
makanan jajanan sehat yang rendah kalori namun bernilai gizi tinggi.

Salah satu makanan jajanan yang sehat dan disukai anak-anak adalah biskuit. Namun biskuit komersial yang beredar di pasaran seringkali mengandung zat gizi yang kurang seimbang, seperti tinggi karbohidrat dan lemak tetapi rendah protein. Pembuatan biskuit dengan bahan pangan sumber protein dapat meningkatkan kandungan proteinnya. Namun mutu protein bahan pangan tidak hanya ditentukan oleh kandungan protein, tetapi juga oleh kemampuan dan ketersediaan protein tersebut dicerna dan diserap tubuh. Salah satu parameter mutu protein adalah nilai cernanya yang didefinisikan sebagai efektivitas absorpsi protein oleh tubuh. ${ }^{3}$

Bahan pangan sumber protein antara lain kedelai yang mengandung protein yang tinggi sebesar 35 gram per 100 gram bahan dan mengandung asam amino esensial maupun non esensial yang jumlahnya melebihi referensi FAO, terutama asam amino esensial lisin., ${ }^{4,5}$ Namun kedelai mengandung senyawa antinutrisi yang dapat membatasi kerja enzim pencernaan, seperti protease inhibitor, hemaglutinin dan asam fitat, sehingga dapat menurunkan nilai cerna proteinnya. Salah satu metode yang efektif untuk mengurangi senyawa antinutrisi tersebut yaitu dengan proses perkecambahan. $^{6}$

Perkecambahan merupakan proses katabolis zat gizi melalui reaksi hidrolisis dari zat gizi cadangan yang terdapat dalam biji. Perkecambahan dapat meningkatkan mutu protein kedelai dengan meningkatkan jumlah asam amino esensial dengan bantuan enzim proteolitik sehingga nilai cerna protein dan availabilitas asam amino meningkat. ${ }^{7,8}$ Perkecambahan juga dapat mengeliminasi senyawa antinutrisi pada kedelai. Terdapat korelasi negatif antara nilai cerna dan bioavailabilitas zat gizi dengan jumlah antinutrisi pada kecambah kedelai. ${ }^{6}$

Di sisi lain, perkecambahan kedelai menyebabkan timbulnya aroma langu (off flavor) akibat enzim lipoksigenase yang bereaksi dengan udara dan air saat proses perkecambahan. ${ }^{9}$ Aroma langu tersebut masih dapat teridentifikasi pada produk tepung sehingga biskuit yang dihasilkan kurang dapat diterima konsumen. Maka diperlukan bahan pangan lain yang memiliki aroma harum sehingga dapat menutupi aroma langu dari tepung kecambah kedelai tersebut. Salah satu bahan pangan yang memiliki aroma harum yaitu pisang. Pisang juga kaya akan vitamin, mineral dan serat pangan. ${ }^{10}$ Pada pembuatan biskuit dengan penambahan $20 \%$ tepung pisang sebagai substitusi terigu dapat memberikan aroma yang disukai panelis. ${ }^{11}$ Jenis pisang yang digunakan yaitu pisang dari jenis banana yang memiliki aroma harum, seperti pisang susu. ${ }^{12}$ Selain harganya murah, jenis pisang ini sangat disukai karena rasanya yang manis sehingga dapat menumbuhkan kesukaan terhadap buah pada anak-anak.

Kecambah kedelai matang (germinated cooked) memiliki nilai cerna protein sebesar $95 \%$, sementara terigu yang biasanya digunakan sebagai bahan baku biskuit komersial memiliki nilai cerna protein sebesar $96 \% .{ }^{13,14}$ Pembuatan biskuit dengan substitusi kecambah kedelai dan pisang dimaksudkan agar dapat mengimbangi nilai cerna protein biskuit dari terigu yang sudah tinggi, meningkatkan kandungan gizi dan nilai sensoris biskuit sehingga cocok menjadi makanan jajanan sehat untuk anak sekolah dasar.

\section{METODE}

Penelitian ini termasuk dalam bidang food production yang dilakukan pada bulan Oktober sampai November 2014 di Laboratorium Rekayasa dan Hasil Pertanian Universitas Semarang untuk pembuatan bahan baku tepung kecambah kedelai, tepung pisang dan biskuit, serta di Laboratorium Mikrobiologi dan Biokimia Gedung PAU Institut Pertanian Bogor untuk menguji nilai cerna protein in vitro biskuit.

Penelitian ini merupakan penelitian eksperimental dengan rancangan acak lengkap satu faktor, yaitu persentase substitusi tepung kecambah kedelai dan tepung pisang dalam pembuatan biskuit. Terdapat 5 taraf perlakuan yang dapat dilihat pada tabel 1. Persentase substitusi tepung kecambah kedelai dan pisang ditentukan berdasarkan estimasi perhitungan total kandungan gizi bahan baku biskuit meliputi jumlah kalori dan protein sesuai dengan Pedoman Pelaksanaan Penyediaan Makanan Tambahan Anak Sekolah (PMT-AS) bagi Siswa RA dan MI sebesar 300 kkal dan 5 gram protein dengan menggunakan program Nutrisurvey for Windows. ${ }^{15}$ Penelitian ini dilakukan dengan 3 kali pengulangan yang dianalisis secara simplo untuk nilai cerna protein in vitro biskuit.

Bahan baku yang digunakan dalam pembuatan biskuit dengan substitusi kecambah kedelai dan pisang adalah tepung kecambah kedelai, tepung pisang yang dibuat dari jenis pisang susu, dan tepung terigu protein rendah, sedangkan bahan pelengkap lainnya meliputi telur, gula halus, margarin, susu skim bubuk, baking powder, vanili, dan garam. 
Tabel 1. Perlakuan Biskuit dengan Substitusi Kecambah Kedelai dan Pisang

\begin{tabular}{cccc}
\hline \multirow{2}{*}{ Formulasi } & \multicolumn{3}{c}{ Jenis Bahan } \\
\cline { 2 - 4 } & Tepung Terigu & $\begin{array}{c}\text { Tepung } \\
\text { Kecambah Kedelai }\end{array}$ & Tepung Pisang \\
\hline $\mathrm{B}_{0}$ & $100 \%$ & $0 \%$ & $0 \%$ \\
$\mathrm{~B}_{1}$ & $75 \%$ & $12,5 \%$ & $12,5 \%$ \\
$\mathrm{~B}_{2}$ & $50 \%$ & $25 \%$ & $25 \%$ \\
$\mathrm{~B}_{3}$ & $25 \%$ & $37,5 \%$ & $37,5 \%$ \\
$\mathrm{~B}_{4}$ & $0 \%$ & $50 \%$ & $50 \%$ \\
\hline
\end{tabular}

Pembuatan biskuit diawali dengan pembuatan tepung kecambah kedelai dan tepung pisang. Tepung kecambah kedelai dan tepung pisang dibuat melalui proses blanching, pengeringan dengan cabinet dryer pada suhu $50^{\circ} \mathrm{C}$ selama $20 \mathrm{jam}$, penggilingan dan pengayakan dengan ukuran 80 mesh. Pada pembuatan tepung pisang setelah proses blanching dilakukan pengecilan ukuran pisang dan perendaman pada larutan asam sitrat $0,3 \% \mathrm{w} / \mathrm{v}$ atau $3 \mathrm{~g} / \mathrm{L}$ untuk mencegah terjadinya enzymatic browning pada pisang. ${ }^{16,17}$ Kemudian dilanjutkan dengan pembuatan biskuit melalui proses pencampuran bahan basah meliputi telur, gula halus, margarin, dan susu skim dengan mixer selama 5 menit, lalu penambahan bahan kering meliputi ketiga jenis tepung, baking powder, vanili, dan garam pada campuran bahan basah tersebut, homogenisasi dengan mixer, pencetakan dan pemanggangan dalam oven dengan suhu $130^{\circ} \mathrm{C}$ selama 15 menit.

Data yang dikumpulkan pada penelitian ini adalah nilai cerna protein in vitro biskuit dengan substitusi kecambah kedelai dan pisang. Metode yang digunakan untuk analisis nilai cerna protein in vitro menggunakan metode multienzim meliputi enzim tripsin, kimotripsin dan peptidase.${ }^{18,19}$ Prinsip metode multienzim ini yaitu menghidrolisis sampel protein oleh campuran enzim-enzim tersebut sehingga terjadi penurunan $\mathrm{pH}$ suspensi dan nilai $\mathrm{pH}$ pada menit ke-10 dicatat untuk menghitung nilai cerna protein sampel menggunakan suatu persamaan regresi, yaitu $\mathrm{Y}=210.464-18.103 \mathrm{X}$; dimana $\mathrm{Y}$ adalah nilai cerna protein $(\%)$ dan $\mathrm{X}$ adalah $\mathrm{pH}$ suspensi sampel protein pada menit ke$10 .{ }^{19}$

Uji normalitas data menggunakan Shapirowilk dan uji Kruskal-Wallis untuk melihat perbedaan nilai cerna protein pada seluruh kelompok perlakuan. Uji dilanjutkan dengan uji posthoc Mann-Whitney untuk mengetahui adanya beda bermakna antar kelompok perlakuan dan kontrol.

\section{HASIL}

Hasil analisis data nilai cerna protein biskuit dengan substitusi kecambah kedelai dan pisang dapat dilihat pada Tabel 2.

Tabel 2. Nilai Cerna Protein Biskuit dengan Substitusi Kecambah Kedelai dan Pisang

\begin{tabular}{lc}
\multicolumn{1}{c}{ Perlakuan } & $\begin{array}{c}\text { Nilai Cerna Protein (\%) } \\
\text { Rerata } \pm \text { SD }\end{array}$ \\
\hline $\mathrm{B}_{0}$ (kontrol) & $96.5 \pm 0.8^{\mathrm{a}}$ \\
$\mathrm{B}_{1}$ (substitusi kecambah kedelai \& pisang 12,5\%) & $93.1 \pm 0.2^{\mathrm{b}}$ \\
$\mathrm{B}_{2}$ (substitusi kecambah kedelai \& pisang 25\%) & $90.4 \pm 4.9^{\mathrm{bcd}}$ \\
$\mathrm{B}_{3}$ (substitusi kecambah kedelai \& pisang 37,5\%) & $91.3 \pm 0.6^{\mathrm{c}}$ \\
$\mathrm{B}_{4}$ (substitusi kecambah kedelai \& pisang 50\%) & $88.9 \pm 0.2^{\mathrm{d}}$ \\
\hline
\end{tabular}

Keterangan : Angka yang diikuti huruf superscript (a,b,c,d) berbeda menunjukkan beda bermakna

Hasil uji statistik Kruskal-Wallis menyatakan bahwa terdapat perbedaan nilai cerna protein yang bermakna pada seluruh kelompok biskuit $(\mathrm{p}=0.032)$ dan secara keseluruhan terjadi penurunan nilai cerna protein pada seluruh kelompok biskuit dengan substitusi kecambah kedelai dan pisang. Terdapat perbedaan nilai cerna protein yang bermakna antara kelompok biskuit kontrol $\left(\mathrm{B}_{0}\right)$ dengan semua kelompok biskuit substitusi kecambah kedelai dan pisang $\left(B_{1}, B_{2}, B_{3}\right.$, $\mathrm{B}_{4}$ ), namun tidak ada perbedaan nilai cerna protein yang bermakna antara kelompok biskuit substitusi kecambah kedelai dan pisang $25 \%\left(\mathrm{~B}_{2}\right)$ dengan kelompok biskuit substitusi kecambah kedelai dan pisang $12,5 \%\left(\mathrm{~B}_{1}\right), 37,5 \%\left(\mathrm{~B}_{3}\right)$ dan $50 \%\left(\mathrm{~B}_{4}\right)$. Biskuit pada kelompok kontrol memiliki rerata nilai cerna protein tertinggi (96.5\%), sedangkan biskuit dengan substitusi kecambah kedelai dan pisang $50 \%$ memiliki rerata nilai cerna protein terendah (88.9\%). 


\section{PEMBAHASAN}

Mutu protein suatu bahan pangan dapat dikatakan baik apabila mengandung asam amino esensial yang susunannya lengkap dan komposisinya yang sesuai dengan kebutuhan tubuh, serta memiliki nilai cerna protein yang tinggi. Nilai cerna protein adalah besarnya kemampuan suatu protein untuk dihidrolisis menjadi asam-asam amino oleh enzim pencernaan (protease) yang selanjutnya akan diserap dan digunakan oleh tubuh. ${ }^{3}$ Nilai cerna protein pada suatu bahan pangan dipengaruhi oleh proses pengolahan, adanya senyawa antinutrisi, dan adanya reaksi antara protein dengan senyawa lain yang terdapat dalam bahan pangan tersebut, seperti alkali, metal, lipid, asam nukleat, selulosa atau polisakarida lainnya. ${ }^{20}$

Meskipun kedelai memiliki kandungan protein yang tinggi dan komposisi asam amino yang lengkap, namun nilai cerna protein pada biji kedelai dan tepung kedelai tidak begitu tinggi, yaitu masing-masing sebesar $76 \%$ dan $86 \% .{ }^{14}$ Hal ini disebabkan kedelai mengandung senyawa antinutrisi yang dapat membatasi kerja enzim pencernaan. Perkecambahan dapat meningkatkan nilai cerna protein dengan peran enzim proteolitik dalam merombak molekul-molekul protein dari selsel penyimpanan pada kedelai sehingga menghasilkan suatu campuran asam-asam amino bebas. ${ }^{8}$ Suatu penelitian menunjukkan adanya peningkatan jumlah asam amino bebas sebesar $42 \%$ antara biji kedelai dengan kecambah kedelai seiring dengan lamanya waktu perkecambahan. ${ }^{7}$ Tingginya jumlah asam-asam amino bebas tersebut menunjukkan ketersediaan asam amino yang dapat diserap oleh tubuh tinggi (availabilitas tinggi). Salah satu indikator dari availabilitas protein adalah nilai cerna protein. ${ }^{8}$

Berdasarkan hasil analisis data pada Tabel 2, nilai cerna protein biskuit berkisar antara 88.9$96.5 \%$. Hal ini dapat diartikan bahwa dengan konsumsi protein biskuit sebanyak 100 gram, maka protein yang tercerna sebanyak 88.9-96.5 gram sedangkan sisanya dibuang melalui feses. Terdapat perbedaan nilai cerna protein yang bermakna antara kelompok biskuit kontrol dengan biskuit yang disubstitusi kecambah kedelai dan pisang. Hal ini menunjukkan bahwa substitusi bahan kecambah kedelai dan pisang pada pembuatan biskuit belum mampu mengimbangi tingginya nilai cerna protein biskuit kontrol. Terjadi penurunan nilai cerna protein biskuit seiring dengan meningkatnya persentase substitusi kecambah kedelai dan pisang.

Semakin rendahnya nilai cerna protein pada biskuit dengan penambahan substitusi kecambah kedelai dan pisang ini dapat disebabkan oleh salah satu bahan baku pembuatan biskuit yaitu terigu. Terigu memiliki nilai cerna protein yang cukup tinggi sebesar $96 \% .{ }^{14} \mathrm{Hal}$ ini menyebabkan biskuit kontrol memiliki nilai cerna protein yang hampir menyamai nilai cerna protein terigu yaitu sebesar 96.5\%. Persentase terigu pada kelompok biskuit kontrol sebesar $100 \%$, sedangkan penggunaan terigu pada 4 kelompok biskuit dengan substitusi kecambah kedelai dan pisang semakin berkurang seiring dengan penambahan tepung kecambah kedelai dan pisang. Penurunan persentase jumlah terigu dalam pembuatan biskuit yang diikuti peningkatan persentase substitusi kecambah kedelai dapat menjadi faktor penurunan nilai cerna protein pada biskuit.

Menurunnya nilai cerna protein pada biskuit juga dapat dipengaruhi oleh salah satu bahan baku pembuatan biskuit lainnya, yaitu tepung kecambah kedelai. Pada proses perkecambahan terdapat enzim $\alpha$-amilase dan $\beta$-amilase yang mengubah pati menjadi dekstrin yang kemudian terurai menjadi maltosa. Pada proses respirasi maltosa dipecah menjadi glukosa dan fruktosa sehingga jumlah total gula terlarut meningkat. ${ }^{21}$ Glukosa dan fruktosa merupakan gula pereduksi yang apabila bereaksi dengan asam amino dapat memicu terbentuknya reaksi Maillard yang dapat menurunkan kualitas dari produk makanan yang dihasilkan, salah satunya dengan menurunnya nilai cerna protein. ${ }^{22}$

Reaksi Maillard sendiri merupakan reaksi antara asam amino dengan gula pereduksi. Reaksi tersebut menyebabkan terbentuknya ikatan silang (cross linkage) antara asam-asam amino yang terletak di dalam molekul protein sehingga terjaga dari serangan enzim. Akibatnya asam-asam amino tersebut tidak dapat dihidrolisis dari ikatan peptida proteinnya oleh enzim proteolitik sehingga menyebabkan asam amino menjadi tidak tersedia bagi tubuh. ${ }^{22}$

Reaksi Maillard juga dapat diakibatkan oleh tepung pisang yang digunakan dalam pembuatan biskuit. Tepung pisang berasal dari jenis pisang susu yang memiliki karakteristik aroma yang harum saat buah sudah matang penuh agar dapat menutupi aroma langu yang ditimbulkan tepung kecambah kedelai. Namun pisang yang sudah matang ini mengandung gula total sebesar 19,28\% sehingga apabila berikatan dengan asam amino yang berasal dari tepung kecambah kedelai juga dapat menyebabkan reaksi Maillard yang dapat menurunkan nilai cerna protein biskuit. ${ }^{12}$

Serat pangan dapat menjadi faktor menurunnya nilai cerna protein pada biskuit. Tepung pisang mengandung serat pangan sebesar 
7,6 gram/100 gram, sedangkan serat pangan pada tepung kecambah kedelai cukup tinggi sebesar 25,54 gram/100 gram. ${ }^{10,23}$ Tingginya kandungan serat pangan pada tepung kecambah kedelai disebabkan bahan baku kecambah kedelai yang ditepungkan meliputi bagian kotiledon dan hipokotilnya. Bagian hipokotil kecambah kedelai akan membentuk jaringan penguat sel atau dinding sel pada sumbu pertumbuhan embrio untuk pertumbuhan akar dan batang. ${ }^{23}$ Hal ini menyebabkan ketika bagian tersebut dikeringkan dan digiling akan menghasilkan tepung yang memiliki kadar serat tinggi.

Serat pangan dapat mempengaruhi aktivitas enzim-enzim protease. Penurunan aktivitas enzimenzim tersebut disebabkan karena pengikatan atau interaksi oleh serat pangan. Apabila serat pangan berikatan dengan protein, enzim protease akan sulit untuk melakukan penetrasi untuk memutus ikatan peptidanya. Hal ini menyebabkan protein tersebut tidak dapat tercerna dengan baik sehingga nilai cerna proteinnya menurun dan absorpsi asam amino menjadi kurang efisien. ${ }^{24}$

Secara keseluruhan semua kelompok biskuit memiliki nilai cerna protein yang relatif tinggi (88.9-96.5\%). Hal ini menunjukkan bahwa biskuit tersebut mengandung protein yang mudah dicerna sehingga mampu menyediakan asam amino dalam jumlah yang banyak serta siap diserap dan digunakan oleh tubuh. Biskuit tersebut juga cocok bagi anak sekolah dasar yang membutuhkan protein dengan mutu yang baik untuk menunjang pertumbuhan dan perkembangannya.

\section{SIMPULAN}

1. Secara keseluruhan semua kelompok biskuit, baik kontrol maupun dengan substitusi kecambah kedelai dan pisang memiliki nilai cerna protein yang tinggi, yaitu kelompok B1 sebesar 96.5\%, kelompok B2 sebesar 93.1\%, kelompok B3 sebesar 90.4\%, kelompok B4 sebesar 91.3\% dan kelompok B5 sebesar $88.9 \%$.

2. Terjadi penurunan nilai cerna protein seiring dengan penambahan substitusi tepung kecambah kedelai dan pisang.

\section{SARAN}

Untuk mengurangi penurunan nilai cerna protein pada biskuit, pembuatan tepung kecambah kedelai menggunakan bahan baku kecambah kedelai bagian kotiledonnya saja sehingga serat pangan yang terkandung pada tepung kecambah kedelai tidak terlalu tinggi.

\section{DAFTAR PUSTAKA}

1. Mariza, Yuni Yanti. Hubungan antara Kebiasaan Sarapan dan Kebiasaan Jajan dengan Status Gizi pada Anak Sekolah Dasar di Kecamatan Pedurungan Kota Semarang. Skripsi. Program Studi Ilmu Gizi Fakultas Kedokteran Universitas Diponegoro. 2012.

2. Suryaalamsah, Inne Indraaryani. Konsumsi Fast Food dan Faktor-Faktor yang Berhubungan dengan Kegemukan Anak Sekolah di SD Bina Insani Bogor. Tesis. Sekolah Pascasarjana Institut Pertanian Bogor. 2009.

3. Muchtadi, Deddy. Teknik Evaluasi Nilai Gizi Protein. Alfabeta : Bandung. 2010. p 2-3.

4. Persatuan Ahli Gizi Indonesia. Tabel Komposisi Pangan Indonesia. Jakarta. 2009.

5. Burssens S, Pertry I, Ngudi DD, Kuo YH, Montagu MV, and Lambein F. Soya, Human Nutrition and Health. Institute Plant Biotechnology for Developing Countries. Ghent University Belgium.

6. Ghavidel RA and Prakash J. The Impact of Germination and Dehulling on Nutrients, Antinutrients, In Vitro Iron and Calcium, Bioavailability and In Vitro Starch and Protein Digestibility of Some Legume Seeds. LWT. 2007; $40: 1292-9$.

7. Kim SL, Lee JE, Kwon YU, Kim WH, Jung GH, Kim DW et al. Introduction and Nutritional Evaluation of Germinated Soygerm. Food Chemistry. 2013; 136 : 491-500.

8. Luo Y, Jin X, Hao Z, Wang Q, Zhu L, and He Y. Effect of Sprouting on Amino Acids, Protein Solubility and Availability in Green and White Faba Bean (Vicia faba L.). Adv. J. Food Sci and Technol. 2014; 6(4) : 531-6.

9. Kumar V, Rani A, Pandey V, and Chauhan GS. Changes in Lipoxygenase Isozyme and Trypsin Inhibitor Activity in Soybean during Germination at Different Temperatures. Food Chemistry. 2006 ; 99 : 563-8.

10. Aurore G, Parfait B, and Fahrasmane L. Bananas, Raw Materials for Making Processed Food Products. Trends in Food Science \& Technology. $2009 ; 20: 78-91$.

11. Oyeyinka SA, Oyeyinka AT, Karim OR, Toyeeb KA, Olatunde SJ, and Arise AK. Biscuits Making Potentials of Flour from Wheat and Plantain at Different Stages of Ripeness. Croat. J. Food Sci. Technol. 2014 ; 6(1) : 36-42.

12. Prabawati, Sulusi; Suyanti, dan Dondy A Setyabudi. Teknologi Pascapanen dan Teknik Pengolahan Buah Pisang. Badan Penelitian dan Pengembangan Pertanian. 2008.

13. Akporhonor EE, Egwaikhide PA, and Eguavoen IO. Effect of Sprouting on In Vitro Digestibility of Some Locally Consumed Leguminous Seeds. J Appl Sci Environ. 2006 ; 10(3) : 55-8.

14. World Health Organizatition. Protein Quality Evaluation. In WHO Technical Report Series : 
Protein and Amino Acid Requirements in Human Nutrition. Geneva. 2007.

15. Kementerian Agama RI. Pedoman Pelaksanaan Penyediaan Makanan Tambahan Anak Sekolah (PMT-AS) bagi Siswa RA dan MI tahun 2012. Jakarta. 2012.

16. Ioannou I and Ghoul M. Prevention of Enzymatic Browning in Fruit and Vegetables. European Scientific Journal. 2013 ; 9(30) : 310-41.

17. Garcia EJ, Acevedo EA, Ayerdi SGS, Ambriz SLR, and Perez LAB. Composition, Digestibility and Application in Breadmaking of Banana Flour. Plant Foods for Human Nutrition. 2006; 61 : 131-7.

18. Khan MA, Almas K, and Chaudhry HM. Predicting Dietary Protein Quality by An In Vitro Method. Journal of Animal Science. 1980 ; 2 : 43-8.

19. Muchtadi, Deddy. Teknik Evaluasi Nilai Gizi Protein. Alfabeta : Jakarta. 2010. p 155.

20. Maligan, Jaya Mahar. Nutrition and Food Evaluation : Protein. Fakultas Teknologi Pangan Universitas Brawijaya. 2013.

21. Black $M$ and Bewley JD. Editor. Seed Carbohydrates. In Seed Technology and Its Biological Basis. Sheffield Academy Press Ltd : Sheffield. 2000. p 110.

22. Muchtadi, Deddy. Teknik Evaluasi Nilai Cerna Protein. Alfabeta : Bandung. 2010. p 82.

23. Aminah, Siti dan Wikanastri Hersoelistyorini. Karakteristik Kimia Tepung Kecambah Serealia dan Kacang-kacangan dengan Variasi Blanching. Skripsi. Program Studi Teknologi Pangan Universitas Muhammadiyah Semarang. 2012.

24. Schneeman BO. Macronutrient Absorption. In Dietary Fiber : Chemistry, Physiology, and Health Effects. Plenum Press : New York. 1990. p 162-3. 